\title{
Study on the Major Dairy Cows Reproductive Problems in and Around Gondar Town, Northwest Ethiopia
}

\section{Aschalew Ayisheshim, Shimeles Abegaz* and Awole Mohammed}

School of Veterinary Medicine, Wollo University, P.O.Box 1145, Dessie Amhara, Ethiopia

*Corresponding author: Shimeles Abegaz, School of Veterinary Medicine, Wollo University, P.O. Box 1145, Dessie Amhara, Ethiopia, Tel: 251914716612; E-mail: shimhareg776gmail.com

Rec date: December 01, 2016; Acc date: October 27, 2017; Pub date: October 30, 2017

Copyright: (C) 2017 Ayisheshim A, et al. This is an open-access article distributed under the terms of the Creative Commons Attribution License, which permits unrestricted use, distribution, and reproduction in any medium, provided the original author and source are credited.

\begin{abstract}
A cross sectional study was conducted commencing from October 2014 to April 2015 in urban and peri-urban areas of Gondar town, of the Amhara National Regional State of Ethiopia to identify the major reproductive problems in dairy cows. A total of 401 dairy cows were examined for the major reproductive problems by classifying the methods of studying as questionnaire survey and regular follow up. Owner of 401 cows from 80 dairy farms and small holder farmers (households) were questioned for the major reproductive problems and found $100(24.9 \%)$ affected animals and again from 401 dairy cows owner of 100 cows from 15 dairy farms and small holder farmers (households) were regularly followed and out of them $37(37.0 \%)$ have at least one of the reproductive problems. The questionnaire survey of reproductive problems according to their relative importance were $24(6.0 \%)$ anestrous, $18(4.5 \%)$ repeat breeder, $16(4.0 \%)$ endometritis, $15(3.7 \%)$ dystocia, $11(2.7 \%)$ abortion, $8(2.0 \%)$ mixed cases and $7(1.7 \%)$ retained fetal membrane (RFM). Parallel to questionnaire survey regular follow up study was takes place on 100 dairy cows from 15 dairy farms and small holder farmers (households) and out of them $7(7.0 \%)$ anestrous, 6 (6.0\%) abortion, $6(6.0 \%)$ dystocia, $6(6.0 \%)$ endometritis, $5(5.0 \%)$ RFM, $4(4.0 \%)$ mixed cases, and $3(3.0 \%)$ was repeat breeders. SPSS version 20 was used for chi-square test and $p<0.05$ was taken as statistically significant. The prevalence of reproductive problems showed statistically significant difference $(p<0.05)$ with respect to parity, age, body condition score, farm scale, cleanness, methods of service and types of feeding practice, but significantly associated with respect to breed in both questionnaire survey and regular follow methods of study. This result shows no significant difference $(p>0.05)$, between the two study methodology within the reproductive problems. This particular study indicates that an reproductive problem, which includes anoestrus, RFM, abortion, dystocia, endometritis and repeat breeding, were one of the major factor for the low fertilizing ability of dairy cows in urban and peri-urban area of Gondar town. Therefore, the dairy breeders should be providing additional feed to fulfill nutritional requirement of animal, improving cleanness and feeding practice of the animal.
\end{abstract}

Keywords: Dairy Cows; Ethiopia; Gondar; Reproductive problems; Urban; Peri-urban

\section{Introduction}

The world's dairy production is estimated to be 612 million tones, of which 514 million tones is cow milk and nearly 1 million from other species. World dairy production is increasing at the rates of 3 million tones annually with a long term growth, although it varies in the short and medium terms [1]. Asia is the largest dairy consuming region. It is also the largest importing region with over one half of global imports of dairy products. Imports are contnuining to grow drive largely by rapid income growth and urbanization and demand is exceeding supply. Milk production in developing countries expected to increase $4.5 \%$ in 2006 , compared with $1.1 \%$ in developed countries. Even at a low base, milk production is growing slowly in least developed countries [2].

First small holder dairy households keep the majority of the cattle in Ethiopia accounting for $97 \%$ of all milk produced and $75 \%$ of commercial milk production. Secondly state farms that have been privatized or are in the process of privatization are using high grade animals. The third groups are peri urban and urban households, mainly keeping cross breed animals [3].
In Ethiopia as many developing countries, livestock play multiple roles. Despite the huge number of cattle and their economic importance, the productivity is low due to the constraints of disease, poor nutrition, poor management and poor performance of dairy cows. Among the major problems that have direct impact on productivity of dairy cows are abortion, dystocia, retained fetal membrane, anestrous, endometritis and repeat breeder. These could be classified as pre-partum and postpartum reproductive problems [4].

Reproductive problem is inability of the female or male to reproduce. Insidious but great losses are directly due to failure to breed on the part of otherwise promising animals. This loss is made up by the keep of the barren animals that absence of offspring, reduction of milk supply and interferences with breeding programs [5]. Regular breeding depends up on the normal function of the reproductive system. In order to breed regularly, the cow has to have functional ovaries, display estrus behavior, mate, conceive sustain the embryo through gestation, calve and resume estrus cycles and restore uterine function after calving [6].

Cows culled for "reproductive problems" are usually described as barren (infertile). However, the majority of cows culled for reproductive problem reasons are likely to be perfectly normal anatomically and capable of becoming pregnant given the right management [7]. 
Reproductive problem is due to multiple causes often not directly related to the endocrine system. A complete history should be obtained, clinical examination of genital tract and per rectum and vagina by speculum should be made, and a physical examination of the cow might be necessary so that an accurate differential diagnosis is possible [8].

Major reproductive problems are greatly responsible for higher economic loss in dairy cows, the research done on the prevalence, etiology and relative importance of these problems in dairy cows in urban and peri-urban area of Gondar was less. So this study is designed to find out the magnitude of major reproductive problems in dairy cows in urban and per urban area of Gondar, to collect base line data for future study in this area and to forward possible recommendations for the control approaches. Therefore, the objective of this study is to identify major reproductive problems in dairy cows associated with anestrus, retained fetal membrane (RFM), dystocia, repeat breeding, endometritis and abortion in urban and peri-urban area of Gondar town.

\section{Materials and Methods}

\section{Study area}

The study was conducted in and around Gondar town in different dairy farm and small holder farmers. The town is located in Northwest part of Ethiopia at a distance of about $750 \mathrm{~km}$ from Addis Ababa the capital city of Ethiopia. It is located on $35^{\circ} 7^{\prime} \mathrm{N}$ and $13^{\circ} 8^{\prime} \mathrm{E}$ and lies at an altitude of 2200 meter above sea level. The area receives mean annual rain fall of $1172 \mathrm{~mm}$ mainly in rainy season with average temperature of $19.7^{\circ} \mathrm{C}$. The region receives a bimodal rainfall, the average annual precipitation rate being $1000 \mathrm{~mm}$ that comes from the long and short rainy seasons. The short rainy season occur during the months of March, April and May while the long ones extend from June through September [9]

\section{Study animals}

The study animals were dairy cattle, which includes lactating pregnant, lactating non-pregnant, dry pregnant and dry non-pregnant dairy cows for questionnaire survey and purposively selected $3 \mathrm{rd}$ trimester pregnant cows for regular follow up study that found in and around Gondar town.

\section{Sample size determination}

The sample size required for the study was determined according to the formula given by Thrusfiled, M. (2005) [10]. Since there was no any similar report in the study area, so $50 \%$ expected prevalence was taken.

$\mathrm{N}=\left[1.96^{2} \times \mathrm{P}_{\exp }\left(1-\mathrm{P}_{\exp }\right)\right] / \mathrm{d}^{2}$ Where: $\mathrm{N}=$ sample size; $\mathrm{P}_{\exp }=\operatorname{expected}$ prevalence $\mathrm{D}=$ desired absolute precision. So, $\mathrm{N}=\left[1.96^{2} \times 0.5(1-0.5)\right] /$ $0.05^{2}=384$.

But to increase the precision of the study 17 dairy cows were added and total of 401 animals were taken for the questionnaire survey and 100 animals were taken for regular follow up study.

\section{Study design}

A cross-sectional study was conducted from October 2014 to April 2015 in and around Gondar town for questionnaire survey and longitudinal study for regular follow up. Active data was generated from randomly selected dairy farms and individual smallholder farmers and purposively selecting dairy cows with regard to age breed, and farm scale, methods of service, feeding practice, body condition score, and hygienic states (house and animal) were considered as risk factors to test for occurrence of reproductive problems.

\section{Sampling method}

The sampling methods of this study were random sampling method was used to select the dairy farm and smallholder farmers as well as Purposive sampling was used to select the sampling units.

\section{Study methods}

The study was conducted by cross sectional questionnaire survey and longitudinal regular follow up.

Questionnaire survey: In questionnaire survey a total of 401 dairy cows were examined from 80 dairy farms and smallholder farmers for the majority of reproductive problems in dairy cows in and around Gondar town by distributing questionnaire paper

Regular follow up: During regular follow up study, different methods of diagnosis was used to detect major reproductive problems which was encountered in dairy cows; to identify this problem, regular follow up of the cows was performed once per three week and the result was recorded in follow up data collection sheet. If a cow has not been shown estrus by 60 days post partum period record as anestrus, if the cow has not been conceived from three or more regularly spaced service recorded as repeat breeder, if the fetal membrane of the cow has not been removed or expelled within $24 \mathrm{hrs}$. of postpartum period recorded as retained fetal membrane RFM, if the cow had parturition problem recorded as dystocia, if the cow had delivered fetus before full gestation period recorded as abortion, if the cow has vaginal discharge after parturition was recorded as endometrities, if the uterus be distended and filled with pus after trans rectal palpation recorded as pyometra with the persistence of corpus luteam (CL), and after rectal palpation either follicular cyst (bluster like structure) or luteinized cyst (firm like structure) was recorded as cystic ovaries [11].

\section{Data management and analysis}

The data was checked, coded and entered in to Microsoft excel work sheet and was analyzed using SPSS software version 20. Descriptive statistics like percentage was used to express prevalence, while chisquare $\left(\chi^{2}\right)$ was used to compare the association of reproductive problems with different risk factors. In all the cases, 95\% confidence level and 0.05 absolute precision errors were considered. A p-value $\leq$ 0.05 was considered statistically significant.

\section{Results}

A total of 401 animals were questioned from 80 dairy farms and small holder farmers (households) and found 24 (6.0\%) anestrous, 7 (1.7\%) RFM, 11 (2.7\%) abortion, 15 (3.7\%) dystocia, 16 (4.0\%) endometritis, $18(4.5 \%)$ repeat breeder and $8(2.0 \%)$ mixed cases. Parallel to questionnaire survey regular follow up was takes place on 100 dairy cows from 15 dairy farms and small holder farmers (households) and out of them 7 (7.0\%) anestrous, 5 (5.0\%) RFM, 6 (6.0\%) abortion, $6(6.0 \%)$ dystocia, 6 (6.0\%) endometritis, 3 (3.0\%) repeat breeder and $4(4.0 \%)$ were mixed cases. This result shows a significant association $(\mathrm{p}>0.05)$, between the two study methodology with reproductive problems (Table 1 ). 
Citation: Ayisheshim A, Abegaz S, Mohammed A (2017) Study on the Major Dairy Cows Reproductive Problems in and Around Gondar Town, Northwest Ethiopia. J Vet Sci Technol 8: 484. doi:10.4172/2157-7579.1000484

Page 3 of 7

\begin{tabular}{|l|l|l|l|l|}
\hline Method of study & $\begin{array}{l}\text { Animal } \\
\text { examined }\end{array}$ & $\begin{array}{l}\text { Not } \\
\text { affected }\end{array}$ & Affected & Prevalence \% \\
\hline Questionnaire & 401 & 301 & 100 & 24.9 \\
\hline Follow up & 100 & 63 & 37 & 37 \\
\hline Total & 501 & 364 & 137 & 61.9 \\
\hline
\end{tabular}

Table 1: Major reproductive problems in urban and peri-urban areas of Gondar town.

\begin{tabular}{|c|c|c|c|c|c|c|c|}
\hline $\begin{array}{c}\text { Metho } \\
\text { d }\end{array}$ & & ctors & $\begin{array}{l}\text { Animal } \\
\text { examine }\end{array}$ & $\begin{array}{l}\text { Animal Not } \\
\text { affected }\end{array}$ & $\begin{array}{c}\text { Animal } \\
\text { affected }\end{array}$ & $x^{2}$ & $\begin{array}{c}\mathrm{p}- \\
\text { valu }\end{array}$ \\
\hline & & Local & 158 & 112 (70.9\%) & $\begin{array}{l}46 \\
(29.1 \%)\end{array}$ & & \\
\hline & $\begin{array}{l}\text { Bree } \\
\text { d }\end{array}$ & cross & 179 & $137(76.5 \%)$ & $\begin{array}{l}42 \\
(23.5 \%)\end{array}$ & 2.989 & 0.224 \\
\hline & & exotic & 64 & $52(81.2 \%)$ & $\begin{array}{l}12 \\
(18.8 \%)\end{array}$ & & \\
\hline $\begin{array}{l}\text { Questi } \\
\text { onnair }\end{array}$ & & Total & 401 & $301(75.1 \%)$ & $\begin{array}{l}100 \\
(24.9 \%)\end{array}$ & & \\
\hline $\begin{array}{c}\text { e } \\
\text { survey }\end{array}$ & & $\begin{array}{l}3-6 \\
\text { year }\end{array}$ & 115 & $84(73 \%)$ & $31(27 \%)$ & & \\
\hline & Age & $\begin{array}{l}6.1-10 \\
y r\end{array}$ & 218 & $176(80.7 \%)$ & $\begin{array}{l}42 \\
(19.3 \%)\end{array}$ & 11.92 & 0.03 \\
\hline & & $>10 \mathrm{yr}$ & 67 & 41 (60.3\%) & $\begin{array}{l}27 \\
(39.7 \%)\end{array}$ & & \\
\hline & & Total & 401 & $301(75.1 \%)$ & $\begin{array}{l}100 \\
(24.9 \%)\end{array}$ & & \\
\hline & & Local & 31 & 17 (54.8\%) & $\begin{array}{l}14 \\
(45.2 \%)\end{array}$ & & \\
\hline & $\begin{array}{l}\text { Bree } \\
\text { d }\end{array}$ & cross & 53 & 37 (69.8\%) & $\begin{array}{l}16 \\
(30.2 \%)\end{array}$ & 2.253 & 0.324 \\
\hline & & exotic & 16 & $9(56.2 \%)$ & $7(43.8 \%)$ & & \\
\hline Regula & & Total & 100 & $63(63.0 \%)$ & $\begin{array}{l}37 \\
(37.0 \%)\end{array}$ & & \\
\hline $\begin{array}{l}\text { follow } \\
\text { up }\end{array}$ & & $\begin{array}{l}3-6 \\
\text { year }\end{array}$ & 43 & 31 (71.1\%) & $\begin{array}{l}12 \\
(27.9 \%)\end{array}$ & & \\
\hline & Age & $\begin{array}{l}6.1-10 \\
y r\end{array}$ & 42 & 286 (66.7\%) & $\begin{array}{l}14 \\
(33.3 \%)\end{array}$ & $\begin{array}{l}10.26 \\
2\end{array}$ & 0.006 \\
\hline & & $>10 \mathrm{yr}$ & 15 & $4(26.7 \%)$ & $\begin{array}{l}11 \\
(73.3 \%)\end{array}$ & & \\
\hline & & Total & 100 & $63(63.0 \%)$ & $\begin{array}{l}37 \\
(37.0 \%)\end{array}$ & & \\
\hline
\end{tabular}

Table 2: Prevalence of reproductive problems by breed and age.

Breed and age as risk factors affecting prevalence of reproductive problems. In the above table (Table 2) breed in both questioners and regular follow up shows significantly associated $(p>0.05)$ with reproductive problems but in terms of age there was a significant difference $(\mathrm{p}<0.05)$.

\begin{tabular}{|c|c|c|c|c|c|c|c|}
\hline \multirow{2}{*}{\begin{tabular}{|l|} 
Method \\
$\begin{array}{l}\text { of } \\
\text { study }\end{array}$
\end{tabular}} & \multirow{2}{*}{\multicolumn{2}{|c|}{ Factors }} & \multirow{3}{*}{$\begin{array}{l}\begin{array}{l}\text { Anim } \\
\text { al } \\
\text { exami } \\
\text { ned }\end{array} \\
109\end{array}$} & \multirow{3}{*}{$\begin{array}{l}\begin{array}{l}\text { Animal } \\
\text { not } \\
\text { affected }\end{array} \\
91 \\
(83.5 \%)\end{array}$} & \multirow{3}{*}{$\begin{array}{l}\begin{array}{l}\text { Animal } \\
\text { affected }\end{array} \\
18 \\
(16.55 \%)\end{array}$} & \multirow{3}{*}{$x^{2}$} & \multirow{3}{*}{$\begin{array}{l}\text { p- } \\
\text { valu } \\
\text { e }\end{array}$} \\
\hline & & & & & & & \\
\hline \multirow{10}{*}{$\begin{array}{c}\text { Questio } \\
\text { nnaire } \\
\text { survey }\end{array}$} & \multirow{3}{*}{ Parity } & $\begin{array}{l}\text { Primiparou } \\
\mathrm{s}\end{array}$ & & & & & \\
\hline & & $\begin{array}{l}\text { Multiparou } \\
\mathrm{s}\end{array}$ & 292 & $\begin{array}{l}210 \\
(71.9 \%)\end{array}$ & $\begin{array}{l}82 \\
(28.1 \%)\end{array}$ & 5.675 & $\begin{array}{l}0.01 \\
7\end{array}$ \\
\hline & & Total & 401 & $\begin{array}{l}301 \\
(75.1 \%)\end{array}$ & $\begin{array}{l}100 \\
(24.9 \%)\end{array}$ & & \\
\hline & \multirow{4}{*}{ Farm } & $\begin{array}{l}\text { Small } \\
\text { scale }\end{array}$ & 46 & $\begin{array}{l}37 \\
(80.4 \%)\end{array}$ & $9(19.6 \%)$ & & \\
\hline & & Medium & 95 & $\begin{array}{l}72 \\
(75.8 \%)\end{array}$ & $\begin{array}{l}23 \\
(24.2 \%)\end{array}$ & & \\
\hline & & $\begin{array}{l}\text { Large } \\
\text { scale }\end{array}$ & 260 & $\begin{array}{l}192 \\
(73.8 \%)\end{array}$ & $\begin{array}{l}68 \\
(26.2 \%)\end{array}$ & 0.942 & $\begin{array}{l}0.62 \\
5\end{array}$ \\
\hline & & Total & 401 & $\begin{array}{l}301 \\
(75.1 \%)\end{array}$ & $\begin{array}{l}100 \\
(24.9 \%)\end{array}$ & & \\
\hline & \multirow{3}{*}{\begin{tabular}{|c} 
Feedi \\
ng \\
practi \\
ce
\end{tabular}} & Grazing & 60 & $\begin{array}{l}17 \\
(28.3 \%)\end{array}$ & $\begin{array}{l}43 \\
(71.7 \%)\end{array}$ & & \\
\hline & & Stall & 155 & $\begin{array}{l}128 \\
(82.6 \%)\end{array}$ & $\begin{array}{l}27 \\
(17.4 \%)\end{array}$ & $\begin{array}{l}82.38 \\
2\end{array}$ & 0 \\
\hline & & Both & 186 & $\begin{array}{l}156 \\
(83.9 \%)\end{array}$ & $\begin{array}{l}30 \\
(16.1 \%)\end{array}$ & & \\
\hline & & Total & 401 & $\begin{array}{l}301 \\
(75.1 \%)\end{array}$ & $\begin{array}{l}100 \\
(24.9 \%)\end{array}$ & & \\
\hline \multirow{10}{*}{$\begin{array}{c}\text { Regul } \\
\text { ar } \\
\text { follow } \\
\text { up }\end{array}$} & \multirow{3}{*}{ Parity } & $\begin{array}{l}\text { Primiparou } \\
\mathrm{s}\end{array}$ & 74 & $\begin{array}{l}51 \\
(68.9 \%)\end{array}$ & $\begin{array}{l}23 \\
(31.1 \%)\end{array}$ & & \\
\hline & & $\begin{array}{l}\text { Multiparou } \\
\text { s }\end{array}$ & 26 & $\begin{array}{l}12 \\
(46.2 \%)\end{array}$ & $\begin{array}{l}14 \\
(53.8 \%)\end{array}$ & 4.278 & $\begin{array}{l}0.03 \\
9\end{array}$ \\
\hline & & Total & 100 & $\begin{array}{l}63 \\
(63.0 \%)\end{array}$ & $\begin{array}{l}37 \\
(37.0 \%)\end{array}$ & & \\
\hline & $\begin{array}{l}\text { Small } \\
\text { scale }\end{array}$ & 6 & $\begin{array}{l}5 \\
(83.3 \\
\%)\end{array}$ & $1(16.7 \%)$ & & & \\
\hline & $\begin{array}{l}\text { Medi } \\
=\text { um }\end{array}$ & 40 & $\begin{array}{l}32 \\
(80.0 \\
\%)\end{array}$ & $8(20.0 \%)$ & & & \\
\hline & $\begin{array}{l}n \text { Large } \\
\text { scale }\end{array}$ & 54 & $\begin{array}{l}26 \\
(48.1 \\
\%)\end{array}$ & $\begin{array}{l}28 \\
(51.9 \%)\end{array}$ & 11.133 & 0.004 & \\
\hline & Total & 100 & $\begin{array}{l}63 \\
(63.0 \\
\%)\end{array}$ & $\begin{array}{l}37 \\
(37.0 \%)\end{array}$ & & & \\
\hline & $\begin{array}{l}\text { Grazi } \\
=n g\end{array}$ & 44 & $\begin{array}{l}18 \\
(40.9 \\
\%)\end{array}$ & $\begin{array}{l}26 \\
(59.1 \%)\end{array}$ & & & \\
\hline & Stall & 38 & $\begin{array}{l}29 \\
(76.3 \\
\%)\end{array}$ & 9 (23.7\%) & 17.28 & 0 & \\
\hline & Both & 18 & $\begin{array}{l}16 \\
(88.9 \\
\%)\end{array}$ & $2(11.1 \%)$ & & & \\
\hline
\end{tabular}


Citation: Ayisheshim A, Abegaz S, Mohammed A (2017) Study on the Major Dairy Cows Reproductive Problems in and Around Gondar Town,

Page 4 of 7

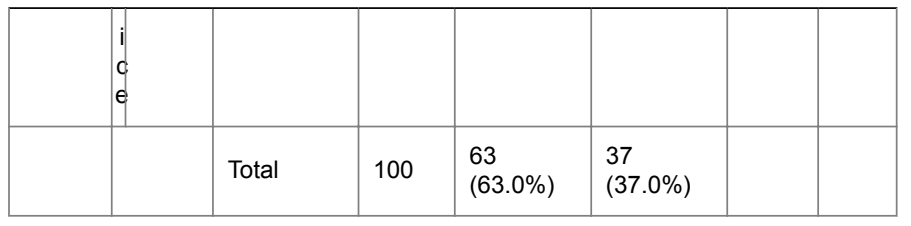

Table 3: Prevalence of reproductive problems by parity, farm scale and feeding practice.
The above table (Table 3), shows a significant association among parity and feeding practice $(\mathrm{p}>0.05)$ with reproductive problems, whereas, farm label in questionnaire survey shows significant association with reproductive problem when we compare with regular follow up which shows significant difference $(\mathrm{p}<0.05)$ with reproductive problem.

\begin{tabular}{|c|c|c|c|c|c|c|c|}
\hline $\begin{array}{l}\text { Method } \\
\text { of study }\end{array}$ & Factors & & Animal examined & Animal not affected & Animal affected & $x^{2}$ & p-value \\
\hline \multirow{8}{*}{$\begin{array}{l}\text { Questionnaire } \\
\text { survey }\end{array}$} & \multirow[t]{4}{*}{ Cleanness } & Poor & 71 & $41(57.7 \%)$ & $30(42.3 \%)$ & \multirow[t]{3}{*}{22.126} & \multirow[t]{3}{*}{0.000} \\
\hline & & Medium & 145 & $103(71.0 \%)$ & $42(29.0 \%)$ & & \\
\hline & & Good & 185 & $157(84.9 \%)$ & $28(15.1 \%)$ & & \\
\hline & & Total & 401 & $301(75.1 \%)$ & $100(24.9 \%)$ & & \\
\hline & \multirow[t]{3}{*}{ Service } & Bull & 111 & $91(82.0 \%)$ & $20(18.0 \%)$ & \multirow[t]{3}{*}{29.586} & \multirow[t]{3}{*}{0.000} \\
\hline & & $\mathrm{Al}$ & 165 & $101(51.2 \%)$ & $64(38.8 \%)$ & & \\
\hline & & Both & 125 & $109(87.2 \%)$ & $16(12.8 \%)$ & & \\
\hline & & Total & 401 & $301(75.1 \%)$ & $100(24.9 \%)$ & \multirow[t]{4}{*}{13.670} & \multirow[t]{4}{*}{0.001} \\
\hline \multirow{8}{*}{$\begin{array}{l}\text { Regular follow } \\
\text { up }\end{array}$} & \multirow[t]{4}{*}{ Cleanness } & Poor & 34 & $13(38.2 \%)$ & $21(61.8 \%)$ & & \\
\hline & & Medium & 19 & $15(78.9 \%)$ & $4(21.1 \%)$ & & \\
\hline & & Good & 47 & $35(74.5 \%)$ & $12(25.5 \%)$ & & \\
\hline & & Total & 100 & $63(63.0 \%)$ & $37(37.0 \%)$ & & \\
\hline & \multirow[t]{3}{*}{ Service } & Bull & 37 & $26(70.3 \%)$ & $11(29.7 \%)$ & \multirow[t]{3}{*}{20.891} & \multirow[t]{3}{*}{0.000} \\
\hline & & $\mathrm{Al}$ & 41 & $16(39.0 \%)$ & $25(61.0 \%)$ & & \\
\hline & & Both & 22 & $21(95.5 \%)$ & $1(4.5 \%)$ & & \\
\hline & & Total & 100 & $63(63.0 \%)$ & 37 (37.0\%) & & \\
\hline
\end{tabular}

Table 4: Prevalence of reproductive problems by cleanness and methods of service.

In the above table (Table 4) all the risk factors (sanitation and service) has highly significant difference with reproductive problem in both methods of study $(\mathrm{p}<0.05)$.

\begin{tabular}{|c|c|c|c|c|c|c|c|}
\hline Method & \multicolumn{2}{|l|}{ factors } & Animal examined & Animal not affected & Animal affected & $x^{2}$ & $p$-value \\
\hline \multirow{6}{*}{$\begin{array}{c}\text { Questionnaire } \\
\text { survey }\end{array}$} & \multirow{6}{*}{$\begin{array}{l}\text { Body condition } \\
\text { score }\end{array}$} & Very poor & 52 & $34(65.4 \%)$ & $18(34.6 \%)$ & \multirow[t]{6}{*}{79.009} & \multirow[t]{6}{*}{0.000} \\
\hline & & Poor & 112 & $53(47.3 \%)$ & $59(52.7 \%)$ & & \\
\hline & & Good & 147 & $130(88.4 \%)$ & $17(11.6 \%)$ & & \\
\hline & & Fat & 60 & $5591.7 \%)$ & $5(8.3 \%)$ & & \\
\hline & & Grossly fat & 30 & $29(96.7 \%)$ & $1(3.3 \%)$ & & \\
\hline & & Total & 401 & $301(75.1 \%)$ & $100(24.9 \%)$ & & \\
\hline $\begin{array}{c}\text { Regular follow } \\
\text { up }\end{array}$ & $\begin{array}{l}\text { Body condition } \\
\text { score }\end{array}$ & Very poor & 11 & $5(45.5 \%)$ & $6(54.5 \%)$ & 52.080 & 0.04 \\
\hline
\end{tabular}




\begin{tabular}{|l|l|l|l|l|l|l|}
\hline & Poor & 24 & $4(16.7 \%)$ & $20(83.3 \%)$ \\
\cline { 2 - 5 } & Good & 357 & $28(80.0 \%)$ & $7(20.0 \%)$ \\
\cline { 2 - 6 } & Fat & 17 & $15(88.2 \%)$ & $2(11.8 \%)$ \\
\cline { 2 - 5 } & Grossly fat & 13 & $11(84.6 \%)$ & $2(15.4 \%)$ & \\
\cline { 2 - 5 } & Total & 100 & $63(63.0 \%)$ & $37(37.0 \%)$ & \\
\hline
\end{tabular}

Table 5: Prevalence of reproductive problems by body condition score.

In case of body condition score there was a significant difference $\mathrm{p}<0.05$, both in questionnaire survey and regular follow up with reproductive problems.

Generally from the above table point of view, we can see that the overall ' $\mathrm{P}$ ' is significant with 7 and 92 degrees of freedom, DF $(7,92)=0.603, p>0.05$. We can conclude that at least two group of study methodology are not significantly different to show the picture of reproductive problems.

\section{DISCUSSION}

The present study revealed that the overall prevalence of reproductive problems in dairy cow were $24.9 \%$ and $37.0 \%$ in questionnaire survey and regular follow up respectively. The prevalence of regular follow up was similar with the reports of the previous studies which was conducted by [12], 36.21\% in and around Nazareth town and higher than [13], 24.5\% in and around Bedelle. The prevalence of anestrus (7.0\%) observed in this study was in line with the results of [14] $0.7 \%$ to $20.4 \%$ in Debre Zeit and lower than the reports of the previous studies which were conducted by [15], 10.2\% in Alage dairy farm, [16], 16.4\% in Debre-Zeit, [17] 12.5\% in central Ethiopia and [18], 10.3\% in Borena zone of Southern Ethiopia, which is an important case for the occurrence of infertility problem and it can be suggest the predisposing factor for the occurrence of anestrous were nutritional deficiency, because most of the dairy cow feeding status in this study area were roughage and pasture rather than giving additional feed.

The prevalence rate RFM (5.0\%) in current study was lower than the reports of the previous study which was conducted by [19], 28.9\% in and around Kombolcha, [20], 14.3\% in Debre-Zeit, [15], 26.6\% in Alage dairy farm, [21] 19.2\% in Jimma town, higher than [12], 2.5\% in and around Nazareth town, and closely related with [4], 7.1\% in and around Bedelle, [18] 7.6\% in Borena zone of Southern Ethiopia. The variation in prevalence of RFM may be related to infection, dystocia and its predisposing factors, disease conditions, as well as management difference especially feeding and sanitation.

This study also assessed the prevalence rates of repeat breeding (3.0\%), which was higher than reports of the previous study that was conducted by [12], 1.7\% in and around Nazareth town and has closely associated with [14], 2.5\% in and around Bedelle, but lower than reported by [22], 13\% in and around Awassa, [15], 9.6\% in Mekelle, [18], 10.6\% in borena zone of southern Ethiopia and [23], 10.6\% in central Ethiopia. But this result was similar with [24], 3\% in and around Bedelle, [25], 3.87\% in kombolcha. This variation was may be related with level of malnutrition, sub fertile bull, endocrine imbalance, reproductive tract infections, and poor management practice such as wrong time of insemination or faulty heat detection, inappropriate semen handling and insemination techniques

The prevalence rate of abortion $(6.0 \%)$ recorded in this study was fairly agree with reported earlier [26], 5.4\%, [27], 5.33\%, [28] 6.3\% from Holetta, Kombolcha and Hawassa, respectively. This result also slightly higher than [14], 1.5\% in DebreZeit, [18], 2.91\% in borena zone of southern Ethiopia and lower than [29], 20.2\% in central Ethiopia. This prevalence difference of abortion in dairy cows may be due to differences in environmental conditions and different reproductive diseases like brucellosis, Trichomoniasis, Campylobacteriosis, Leptospirosis and Salmonellosis [30].

The prevalence rate of endometritis (6.0\%) was recorded in this study agree with that of [17], 8.7\% in central Ethiopia. However, a lower prevalence of endometritis was obtained in this work when compared to the results of [31], 19.6\%, [19], 18.7\% and [15], $28.5 \%$ who have reported in Mekelle, in and around Kombolcha and Alage dairy farm respectively. This difference could be possibly due to differences in management systems and postpartum uterine infections like brucellosis [32].

Another important reproductive problem found in the present study was dystocia $6(6.0 \%)$, which was higher than the reports of the previous study conducted by [17], 2.9\% in central Ethiopia, [18], 3.4\% in Borena zone of Southern Ethiopia and [33], 3.3\% in East Showa of Ada'a district. But it was in agreement with [20], 5.8\% that was reports in Debre-Zeit. The variation for the occurrence of dystocia might be due to the fact it was influenced by several factors like nutritional status, age, parity as well as size of fetus and dam. Small sized breeds of cows inseminated with the semen collected from larger sized bulls could be important causes of dystocia [34]

The significantly higher occurrence of reproductive problem was observed in multiparous dairy cows $(53.8 \%)$, which was higher than the previous finding [12], 19.23\% in and around Nazareth town. This higher prevalence of reproductive problems in multiparous dairy cows is due to repeated exposure (repeat breeding) of genital tract to environment that many microorganisms which are live in the environment get opportunity to invade genital tract and then case uterine infection [35].

Significantly higher occurrence of reproductive problem was observed in old age dairy cows $11(73.3 \%)$ than young $12(27.9 \%)$ and adult $14(33.3 \%)$ dairy cows. The significance difference of reproductive problems with respect to age is due to immunity, because as the age increase the animal immunity decreases then the animals become more susceptible and exposed for diseases [36]. The prevalence of reproductive problems was higher in poor cleanness 21 (61.8\%) than other types of cleanness (medium and good cleanness), which may be the animal is easily infected by microorganisms due contaminated 
environment and body of animal. large farm scale 28 (51.9\%) have higher infertility problems than other types of farm scale (small and medium farm scale), may be due overcrowding and fighting one anther leads to traumatic abortion [37].

The prevalence of infertility problems was higher in AI methods of service $25(61.0 \%)$ than natural and both methods of service that might be wrong time of insemination or faulty heat detection, collection of brucellosis infected semen, inappropriate semen handling and insemination technique. Higher prevalence of infertility problems also observed in animal using grazing methods of feeding practice 26 (59.1\%) than other types of feeding practice (stall and both methods). This difference of reproductive problems may be due energy loss of grazing animals in order to search out of their feed.

The current finding of higher prevalence of reproductive problem obtained in cows with relatively poor (83.3\%) and very poor $(54.5 \%)$ body condition score as compare to good $(20.0 \%)$, fat $(11.8 \%)$ and grossly fat (15.4\%) body condition score, this seems to contradict with previous finding, that cows with good body condition score had higher prevalence of reproductive problems than cows with poor body condition score, [12], in and around Nazareth town. Poor body condition score animals are the most susceptible to reproductive health problems due to the weak expulsive force to expel out the fetal membranes leading to secondary bacterial complications.

\section{Conclusion and Recommendations}

The study revealed that reproductive problems particularly associated with anestrus, RFM, repeat breeding, dystocia, abortion and endometrities were one of the major causes of low fertilizing ability in dairy cows in urban and peri-urban area of Gondar town. In this study questionnaire survey (24.9\%) of reproductive problems were found but (37.0\%) of reproductive problems during regular follow up study were recorded in dairy cows. This can imply that it can be responsible for a loss of milk production, a loss of income from calf sales and, a decrease in the replacement rate of cows with first-calving heifers. Multiparous cows, poor cow, old cow and cow found under large scale farm were observed as the most susceptible to reproductive problems. Poor cleanness area, AI methods of service and prolonged permanent pasture land grazing based types of feeding practice were the most predisposing factor for reproductive problem. Generally, anestrus was the main reproductive problem of dairy cattle in the study area which may be due to nutritional deficiency and poor management system. In the view of these facts the following recommendations are forwarded:

- Routine and periodical examination of cows during postpartum period was essential; since most cows acquire uterine infection during this period.

- The dairy breeders should be advised in order to improve cleanness of the animal, provide additional feed to fulfill nutrient requirement of animal, which can minimize the occurrence of reproductive problems or maximize fertilizing ability.

- Training and awareness creation should be given to farmers to increase the fertile ability of dairy cows and livelihood of the dairy farmers through improved management practices and farmers should be given training by experts, how to keep record of their cows, how to de-worm their cattle and how to cull their dairy cows.

- Governmental, non-governmental and livestock rearing community should work together to increase fertility and productivity of livestock.
- Strategies should be designed to develop the dairy sector by taking into account the existing production characteristics of the area and should focus on a systematic approach to formulation and implementation of appropriate plan.

\section{References}

1. Manspeaker J (2009) Retained Placentas: Dairy Integrated Reproductive Management, University of Maryland.

2. Technoserve K (2012b) Online of Ethiopian dairy industry: Dairy sector in Ethiopia.

3. Molalegene B, Shiv P (2011) Study on Major Reproductive Health Problems in Indigeniousand Crossbreed Cow in and around Bedelle, South West of Ethiopia: J Anim Vet Adv 10: 723-727.

4. Boden E (2005) Blacks veterinary dictionary. 21st edn. London: A and C Black, pp: 266-376.

5. Parkinson T (2009) Infertility and subfertility in cow: Philadelphia: Saunders, pp: 393-417.

6. Ball P, Peters A (2004) Reproduction in cattle 3rd edn. Australia: Black well, p: 216.

7. Jainudeen M, Hafez E (2000) Reproduction in Farm Animals. 7th edn. Philadelphia: Lippinoott Williams and Wilkins, pp: 261-269.

8. CSA (2010) Central Statistical Authority: Federal Democratic Republic of Ethiopia, Central Statistical Investigatory, Statistical Report.

9. Thrusfiled M (2005) Veterinary Epidemiology. 3rd edn. Great Britain: Blackwell Science, pp: 253-259.

10. Morrow D (2006) Current therapy in theriogeonology. Diagnosis Treatment and Prevention of Reproductive Disease in Animals. Philadephila: Saunders, p: 326.

11. Takele A, Gizaw Y, Merga B (2005) Major Reproductive Health Problems in Smallholder Dairy Production in and around Nazareth Town, Central Ethiopia: Faculty of Veterinary Medicine, Addis Ababa University, DebreZeit, Ethiopia, pp: 6-17.

12. Zewdu H (1992) Studies on postpartum uterine infection in Zebu and Zebu crosses and the incidence rate of reproductive diseases in DebreZeit, ILCA herd. DVM Thesis, Faculty of Veterinary Medicine, Addis Ababa University, Debre Zeit, Ethiopia.

13. Amene F (2006) Studies on reproductive performance and major reproductive health problems of HF cows at Alage dairy farm. MSc Thesis, Faculty of Veterinary Medicine, Addis Ababa University, Debre Zeit, Ethiopia.

14. Befekadu U (2007) A filed investigation of delayed resumption of postpartum ovarian activity and prolonged postpartum anoestrus in cross breed dairy cows in Debre-Zeit dairy herds. Msc Thesis, Faculty of Veterinary Medicine, Addi Ababa University, Debre-Zeit, Ethiopia.

15. Hadush A, Adem A, Fikru R (2013) Major prepartum and postpartum reproductive problems of dairy cattle in central Ethiopia. J Vet Med Anim Health 5: 118-123.

16. Ararsa D, Wubishet Z (2014) Major reproductive health problems of indigenous Borena cows in Ethiopia. J Adv Vet Anim Res 1: 182-188.

17. Ebrahim O (2003) Study on major reproductive health problem of small Holder dairy farms in and around Kombolcha. DVM, Thesis, Faculty of Veterinary Medicine, Addis Ababa University, Debre Zeit, Ethiopia.

18. Tadelech M (2004) Major postpartum reproductive problems of small holder dairy cows in and around DebreZeit. DVM Thesis, Faculty of Veterinary Medicine, Addis Ababa University, DebreZeit, Ethiopia.

19. Gashaw A, Worku F, Mulugeta S (2011) Assessment of small holder dairy production system and their reproductive health problems in Jimma town South Weast Ethiopia. Int J Appl Res Vet Med 9: 80-86.

20. Micheal K (2003) Major clinical reproductive problem of small holder dairy cows in and around Awassa. DVM Thesis, Faculty of Veterinary Medicine, Addis Ababa University, DebreZeit.

21. Noakes D, Parkinson T, England G (2001) Arthur's Veterinary Reproduction and Obsteterics. 8th edn, China, Saunders, pp: 384-408. 
Citation: Ayisheshim A, Abegaz S, Mohammed A (2017) Study on the Major Dairy Cows Reproductive Problems in and Around Gondar Town, Northwest Ethiopia. J Vet Sci Technol 8: 484. doi:10.4172/2157-7579.1000484

Page 7 of 7

22. Dawit T, Ahmed S (2013) Reproductive health problems of cows under different management systems in kombolcha, Northeast Ethiopia. Adv Biol Res 7: 104-108.

23. Shiferaw Y (1999) Fertility status of dairy cows under different production systems in Holetta central Highland of Ethiopia. MSc Thesis, Faculty of Veterinary Medicine, Addis Ababa University, DebreZeit, Ethiopia.

24. Oumer I (2003) Study on major reproductive health problems of smallholder dairy farms in and around Kombolcha. DVM thesis, Addis Ababa University, Faculty of Veterinary Medicine, Debre Zeit, Ethiopia.

25. Kassahun M (2003) Major clinical reproductive problems of smallholder dairy cows in and around Awassa. DVM thesis. Faculty of Veterinary Medicine, Addis Ababa University, DebreZeit.

26. Tekelye B, Kasali O, Tsion A (1991) Reproductive problems in cross breed cattle in central Ethiopia. Netherlands Anim Reprod Sci 26: 41-49.

27. Vandeplassche M (2000) Reproductive efficiency in castle: A guideline for projects in developing countries. FAO Animal Production and Health Paper No: 25. FAO (Food and Agriculture Organization of the United Nations), Rome, Italy, p: 118.

28. Gebremariam T (1996) Survey on major prepartum and postpartum reproductive problems in dairy cattle in Mekelle and its environments. DVM Thesis, Addis Ababa University, Faculty of Veterinary Medicine, DebreZeit, Ethiopia
29. Merck F, Co G (1998) The Merck Veterinary Manual 8th edn, p: 1017-1026.

30. Getachew E, Nibret M (2014) Major Reproductive Health Disorders in Cross Breed Dairy Cows in Ada'a District, East Shoa, Ethiopia. Global Veterinaria 13: 444-449.

31. Tyler H, Ensminger M (2006) Dairy Cattle Science. 4th edn, p: 371-381.

32. Frazier K, Baldwin C, Pence M, West J, Bernard J, et al. (2002) Seroprevalence and comparison of isolates of endometriotropic Bovine Herpesvirus-4. J Vet Diag Invest 14: 457-462.

33. Wolf D (1993) Management of the repeat breeder female. Saunders Company, Philadelphia, pp: 781-785.

34. Smith P (2009) Large Animal Internal Medicine. 4th edn. USA, Mosby, pp: 1421-1443.

35. Youngquist R, Walter R (2007) Current Therapy in Large Animal Theriogenology. 2nd edn. Saunders Elsevier, pp: 339-373.

36. Arthur G, Noakes D, Pearson H, Pakinson T (2006) Veterinary Reproduction and obstetrics, 7th edn. London: Bailliere Tindall, pp: 291-300.

37. Robertes S (2007) Veterinary Obstetrics and genital diseases. 3rd edn. Mighgar: Edwards's brothers, p: 102. 